\title{
Fenomena (Gegar Budaya) Pada Mahasiswa Perantauan Di Universitas Muslim Indonesia
}

\author{
Hadawiah \\ Universitas Muslim Indonesia \\ Email: hadawiah.hadawiah@umi.ac.id
}

\begin{abstract}
This study aims to describe the underlying causes of the culture shock process in overseas students in Makassar, (2) To describe the impact of culture shock on overseas students at the Indonesian Muslim University. The study used a descriptive qualitative approach. Data collection techniques used in this study were interviews, observation and documentation. The results of the study explain that the factors that encourage students to migrate are: educational factors, economic factors, and cultural factors. The five key informants have expectations or expectations when going abroad and the motives for studying and achieving goals, this is also included in the phase of joy. The process of interaction experienced by Buton, Bima and Papua students overseas was caused by a phase of disillusionment in which there were many differences between hometowns and overseas cities which triggered adjustments to things that were new to the overseas so that there was an exchange of meanings, perceptions and perspectives, so this is included in the initial phase of resolution. To overcome the cultural shock, the three key informants filled out daily activities by joining organizations and communities on and off campus.
\end{abstract}

Keywords: Cultural Concentration, Overseas Students, University of Muslim Indonesia

\begin{abstract}
Abstrak
Penelitian ini bertujuan Untuk mendeskripsikan penyebab yang melatar belakangi proses terjadinya culture shock pada mahasiswa perantauan di Makassar, (2) Untuk mendeskripsikan dampak culture shock pada mahasiswa perantauan di Universitas Muslim Indonesia. Penelitian menggunakan pendekatan kualitatif deskriptif. Teknik pengumpulan data yang digunakan dalam penelitian ini adalah wawancara, observasi dan dokumentasi. Hasil penelitian menjelaskan bahwa faktor yang mendorong mahasiswa untuk merantau adalah: faktor pendidikan, faktor ekonomi, dan faktor budaya. Kelima key informan memiliki harapan atau ekspektasi ketika akan melakukan perantauan serta motif untuk berkuliah dan menggapai cita-cita, hal ini juga termasuk ke dalam fase kegembiraan. Proses interaksi yang dialami oleh mahasiswa Buton,Bima dan Papua di perantauan diakibatkan adanya fase kekecewaan yang dimana terlihat banyaknya perbedaan antara kampung halaman dan kota perantauan sehingga memicu terjadinya penyesuaian terhadap hal-hal yang baru di perantauan sehingga adanya pertukaran makna, persepsi dan perspektif, sehingga hal ini termasuk ke dalam fase awal resolusi. Untuk mengatasi gegar budaya, ketiga key informan mengisi kegiatan sehari-hari dengan mengikuti organisasi maupun komunitas di dalam dan luar kampus.
\end{abstract}

Kata Kunci : Gegar Budaya, Mahasiswa Perantauan, Universitas Muslim Indonesia Al-Munzir Vol. 12. No. 1 Mei 2019 


\section{A. Pendahuluan}

Budaya adalah suatu konsep yang membangkitkan minat. Melalui budaya, setiap individu dapat belajar banyak hal. Mulai dari bagaimana harus menggunakan bahasa, membangun relasi, dan harus berteman. Dengan banyaknya proses dalam keberagaman budaya tertentu, tidak menutup kemungkinan terjadinya proses adaptasi budaya. Adaptasi budaya merupakan sebuah proses individu dalam memadukan kebiasaan pribadinya dan adat istiadat agar sesuai dengan budaya tertentu. Culture shock merupakan hal yang selalu dan hampir pasti terjadi dalam adaptasi budaya. Culture shock sendiri merupakan gejala sosial yang dialami oleh seorang perantau ketika pindah ke daerah dan budaya baru.

Kampus merupakan salah satu tempat terjadinya culture shock, apalagi mahasiswa kampus tersebut terdiri dari berbagai wilayah yang ada di Indonesia tentu menjadikan kampus tersebut rentan terhadap culture shock (Gegar Budaya). Salah satu kampus yang cukup heterogen yang menjadi tempat berkumpulnya mahasiswa di seluruh Indonesia, yang berasal dari latar belakang budaya yang beraneka ragam. Mahasiswa Universitas Muslim Indonesia tidak hanya terdiri dari mahasiswa yang berasal dari Makassar, tapi juga ada mahasiswa yang berasal dari daerah di luar Makassar, seperti Jawa Medan, Padang, Bali, Bandung, Papua, dan wilayah lainnya. Mahasiswa baru (mahasiswa 2016) adalah mahasiswa yang baru memulai untuk beradaptasi dengan lingkungannya. Mahasiswa baru dalam hal ini mahasiswa angkatan 2016 yang mengalami perubahan pada dirinya. Mahasiswa baru biasanya rentan terkena Culture Shock karena mahasiswa baru tersebut harus bersosialisasi dan mengenal budaya baru. Fokus dalam penelitian ini adalah "Bagaimana proses adaptasi mahasiswa perantau Universitas Muslim Indonesia dalam menghadapi Culture Shock?"

Dalam penelitian ini, permasalahan yang ingin diangkat oleh peneliti adalah bagaimana proses adaptasi dalam menghadapi Culture Shock pada mahasiswa perantau angkatan 2016 Universitas Muslim Indonesia dan faktorfaktor apa yang yang menyebabkan terjadinya culture shock pada mahasiswa perantau angkatan 2016 di Universitas Muslim Indonesia. 


\section{B. Metode Penelitian}

Metode penelitian yang digunakan adalah metode penelitian kualitatif yang dapat menggambarkan sedalam-dalamnya suatu fenomena yang akan diteliti. Penelitian kualitatif yang digunakan adalah pendekatan studi kasus, yaitu pendekatan yang menggunakan berbagai sumber data (sebanyak mungkin data) yang bisa digunakan untuk meneliti, menguraikan dan menjelaskan secara komprehensif berbagai aspek individu kelompok suatu program, organisasi atau peristiwa secara sistematis (Kriyantono, 2012:66).

Subjek Penelitian dalam penelitian ini adalah 18 orang mahasiswa perantauan yang tersebar di 13 fakultas di Universitas Muslim Indonesia . Sedangkan yang menjadi informan dalam penelitian ini adalah berjumlah 6 orang. Mereka adalah mahasiswa asal Luar Sulawesi yang sudah dua tahun tinggal di Makassar dan aktif kuliah. Data yang dikumpulkan dari informan di lapangan dalam penelitian ini akan dilakukan dengan proses pengumpulan data yang dilakukan terus-menerus hingga data jenuh. Peneliti akan melakukan reduksi data. Data yang diperoleh dari lapangan yang sangat banyak, sehingga perlu dilakukan analisis data melalui reduksi data. Data dalam penelitian ini dikumpulkan dengan metode wawancara dan observasi. Pemilihan informan dilakukan dengan teknik purposive sampling dan snow ball sampling.

\section{Pembahasan}

Komunikasi merupakan kebutuhan pokok setiap manusia. Komunikasi menjadi perantara satu manusia dengan manusia yang lainnya, sehingga dapat menyampaikan maksud dan tujuan mereka. Dalam kehidupan sehari-hari, tak peduli dimana pun berada, pasti selalu beriteraksi dan berkomunikasi dengan orang-orang tertentu yang berasal dari kelompok, ras, etnis, atau budaya lain. Berinteraksi atau berkomunikasi dengan orang-orang yang berbeda kebudayaan, merupakan pengalaman baru yang selalu dihadapi. Kata komunikasi yang dari bahasa Inggris Communication dan dari bahasa latin Communicatio (yang berasal dari kata communis, yang memiliki arti sama) mengandung maksud kesamaan makna (Mulyana Deddy, 2003:41). Berdasarkan makna kata ini, komunikasi Al-Munzir Vol. 12. No. 1 Mei 2019 
dipahami sebagai suatu kesamaan makna dalam suatu percakapan. Artinya percakapan yang terjadi diartikan sebagai suatu komunikasi, apabila dalam percakapan itu ada kesamaan makna. Komunikasi terjadi setiap saat, hampir $90 \%$ dari kegiatan keseharian manusia dilakukan dengan komunikasi. Manusia tidak bisa meninggalkan proses komunikasi dalam hidupnya. Manusia selalu melakukan penyampaian dan penerimaan pesan tiap waktu, dengan tujuan berbeda di dalamnya. Baik itu hanya sekedar menyampaikan pesan untuk diterima dan dipahami hingga bertujuan untuk mempengaruhi lawan bicaranya agar mengikuti kehendak pembicara.

Salah satu tipe komunikasi adalah Komunikasi Antar Budaya. Komunikasi dan kebudayaan tidak sekedar dua kata tetapi dua konsep yang tidak dapat dipisahkan (William B Hart II, 1996 dalam Liliweri, 2003:8). Studi komunikasi antarbudaya dapat diartikan sebagai studi yang menekankan pada efek budaya terhadap komunikasi. Larry A Samovar, dalam bukunya Komunikasi Lintas Budaya (2010:13) memberikan definisi tentang komunikasi antarbudaya sebagai satu bentuk komunikasi yang melibatkan interaksi antara orang-orang yang persepsi budaya dan simbolnya cukup berbeda dalam suatu komunikasi.

Lewis dan Slade, 1994 (dalam Darmastuti Rini, 2013:68-71) menguraikan tiga kawasan yang paling problematik dalam lingkup pertukaran antarbudaya. Ketiga hal tersebut adalah : (1) kendala bahasa (2) Perbedaan nilai (3) perbedaan pola perilaku budaya .Kendala yang pertama adalah perbedaan bahasa, perbedaan bahasa yang disebabkan karena perbedaan makna dari setiap simbol yang digunakan dalam bahasa seringkali menjadi kawasan yang problematik dalam komunikasi antarbudaya. Selain itu, perbedaan logat, intonasi dan tekanan yang digunakan dalam setiap bahasa juga seringkali menjadi permasalahan yang muncul dalam komunikasi antarbudaya. Kendala yang kedua adalah perbedaan nilai. Perbedaan nilai ini disebabkan karena perbedaan ideologi yang dimiliki oleh setiap budaya. Sebagai contoh, masyarakat Jawa memiliki nilai yang dianut dalam kehidupan mereka yang memandang bahwa "mangan ra mangan asal kumpul". Pandangan ini memiliki nilai dan ideology yang melihat hidup bersama dalam kedekatan ini lebih penting dibandingkan dengan kebutuhan akan makan Ideologi dan nilai ini menjadi dasar dalam kehidupan masyarakat Jawa, akibatnya Al-Munzir Vol. 12. No. 1 Mei 2019 
masyarakat Jawa lebih menekankan hidup bersama dalam kedekatan dibandingkan harus berpisah jauh dan berjuang untuk mendapatkan penghasilan dan pendapatan yang lebih layak. Kendala yang ketiga adalah kendala karena perbedaan pola perilaku budaya. Kendala ini biasanya muncul karena ketidakmampuan masyarakat kita dalam memahami dan menerjemahkan perilaku budaya yang dimiliki oleh masyarakat lainnya.

Perilaku budaya yang teraplikasi dalam sikap dan tindakan mereka seharihari, ataupun dalam tindak komunikasi seringkali diaplikasikan dalam tindakan yang berbeda. Bahkan tidak jarang, sikap dan tindakan itu juga memiliki makna yang berbeda. Selain itu, simbol dan makna yang digunakan oleh suatu masyarakat dari suatu budaya dalam menyampaikan pesannya, seringkali berbeda dengan simbol dan makna yang digunakan oleh masyarakat oleh masyarakat lainnya, karena perbedaan ini, tidak jarang sekelompok masyarakat memberikan penilaian yang negatif terhadap perilaku budaya maupun kebiasan-kebiasan yang dimiliki oleh masyarakat lain. Penilaian negatif ini biasanya disebabkan karena masyarakat tersebut tidak memiliki kemampuan untuk memberikan apresiasi terhadap kebiasan-kebiasan (custom) yang dilakukan oleh kelompok budaya lain. Komunikasi oleh setiap kebudayaan memberikan makna yang beraneka ragam. Masing-masing kebudayaan memiliki sub sistem kebudayaan yang berbeda dan dengan makna yang berbeda pula. Hambatan komunikasi sebagai sesuatu yang menjadi penghalang untuk mencapai komunikasi antarbudaya yang efektif merupakan faktor penyebab kesalahpahaman dalam memandang perbedaan antarbudaya tersebut.

Berbicara mengenai komunikasi antar budaya maka kita dapat membahas tentang adaptasi budaya. Kajian tentang ini didasari oleh pekerja-pekerja imigran dan mahasiwa yang belajar lintas negara di Eropa. Kajian ini dirasa penting untuk menyambut interaksi global yang saat ini sudah menjadi kebiasaan dan semakin banyak terjadi (Judith N.M. dan Thomas K.N, 2003). Para peneliti kemudian berusaha memaparkan dan menjelaskan gejala-gejala sosial serta permasalahanpermasalahan dalam aspek komunikasi yang secara jelas terjadi pada masyarakat global ini. Hingga nantinya ditemukan sebuah model solusi yang bisa 
menyelesaikan atau setidaknya memperkecil aspek-aspek negatif yang bisa tercipta dari komunikasi interkultural.

Ketika seorang jauh dari rumah, jauh dari tempat yang selama ini dianggap sebagai "rumah" jauh dari lingkungan tempat dia tumbuh besar, dan jauh dari kebiasaan-kebiasaan yangs selalu dia lakukan. Orang tersebut mau tidak mau akan sadar atau tidak akan mempelajari hal-hal yang baru untuk bisa bertahan hidup. Ketika seseorang akan jauh dari zona nyamannya untuk waktu yang lama, contohnya kuliah maka akan terjadi transfer- transfer nilai yang biasa kita sebut dengan adaptasi budaya (Ruben dan Stewart, 2006:340). Adaptasi antarbudaya adalah permasalahan mengenai pembelajaran, pengembangan representasi diri, peta, dan image budaya yang tepat, dimana diciptakan oleh adanya hubungan dua orang, kelompok, organisasi, dan masyarakat, yang di dalamnya seseorang menjadi anggotanya. Adaptasi budaya juga melibatkan persuasi yang diberikan berkat pendidikan keluarga, lembaga agama, dan sekolah dimana bertujuan untuk memberikan pengetahuan, nilai-nilai, dan peraturan yang dianggap perlu dalam masyarakat (Brent T.Ruben dan Lea P.Stewart,2006:346). Young Y.Kim (dalam Brent D.Ruben dan Lea P.Stewart, 2006:342) menguraikan dan menggambarkan langkah-langkah dalam proses pengadaptasian sebuah budaya. Secara umum ada empat fase ditambah dengan fase perencanaan. Berikut penjelasan singkat mengenai fase-fase dalam proses pengadaptasian budaya:

(1) Fase Perencanaan, Fase ini adalah fase dimana seseorang masih berada pada kondisi asalnya dan menyiapkan segala sesuatu, mulai dari ketahanan fisik sampai kepada mental,termasuk kemampuan komunikasi yang dimiliki untuk dipersiapkan. Yang nantinya digunakan dikehidupan barunya.

(2) Fase Honeymoon, Fase ini dimana seseorang telah berada dilingkungan baru, menyesuaikan diri dengan budaya baru dan lingkungan. Tahap ini adalah tahap dimana seseorang masih memiliki semangat dan rasa penasaran yang tinggi serta menggebu-gebu dengan suasana baru yang akan dijalani. Individu tersebut mungkin tetap akan merasa asing, kangen rumah dan merasa sendiri namun masih terlena dengan keramahan penduduk lokal terhadap orang asing. 
(3) Fase Frustation, Fase ini adalah tahap dimana rasa semangat dan penasaran yang menggebu-gebu tersebut berubah menjadi rasa frustasi, jengkel dan tidak mampu berbuat apa-apa karena realita yang sebenarnya tidak sesuai dengan ekspetasi yang di miliki pada awal tahapan.

(4) Fase Readjustment, Tahap ini adalah tahap penyesuaian kembali dimana seseorang akan mulai untuk mengembangkan berbagai macam cara untuk bisa beradaptasi dengan keadaan yang ada. Seseorang mulai menyelesaikan krisis yang dialami di fase frustation. Penyelesaian ini ditandai dengan proses penyesuaian ulang dari seseorang untuk mencari cara, seperti mempelajari bahasa, dan budaya setempat.

(5) Fase Resolution, Fase yang terakhir dari proses adaptasi budaya berupa jalan akhir yang diambil seseorang sebagai jalan keluar dari ketidaknyamanan yang dirasakannya. Dalam tahap ini ada beberapa hal yang dapat dijadikan pilihan oleh orang tersebut, seperti: a) Flight, yaitu ketika seseorang tidak tahan dengan lingkungannay dan merasa tidak dapat melakukan usaha untuk beradaptasi yang lebih dari apa yang telah dia lakukan. b) Fight, yaitu orang yang masuk pada lingkungan dan kebudayaan baru dan dia sebenarnya merasa tidak nyaman, namun dia berusaha untuk tetap bertahan dan berusaha menghadapi segala hal yang membuat dia merasa tidak nyaman. c) Accomodation, yaitu tahapan dimana seseorang mencoba untuk menikmati apa yang ada di lingkungannya yang baru, awalnya mungkin orang tersebut merasa tidak nyaman, namun dia sadar bahwa memasuki budaya baru memang akan menimbulkan sedikit ketegangan, maka dia pun berusaha berkompromi dengan keadaan, baik eksternal maupun internal dirinya. d) Full participation, yaitu ketika seseorang sudah mulai merasa nyaman dengan lingkungan dan budaya barunya. Tidak ada lagi rasa khawatir, cemas, ketidaknyamanan, dan bisa mengatasi rasa frustasi yang dialami dahulu. Ini memungkinkan individu untuk berinteraksi dengan anggota-anggota budaya lainnya yang juga memiliki pola-pola komunikasi serupa. Proses memperoleh pola- pola demikian oleh individu itu disebut enkulturasi (Mulyana dan Rakhmat, 2005: 138). 
Secara psikologis, dampak dari akulturasi adalah stress pada individuinvidu yang berinteraksi dalam pertemuan budaya tersebut. Fenomena ini diistilahkan dengan gegar budaya (culture shock). Pengalaman-pengalaman komunikasi dengan kontak antarpersonal secara langsung seringkali menimbulkan frustasi. Istilah culture shock diperkenalkan oleh seorang antropolog yang bernama Kalvero Oberg pada tahun 1960. Kalervo Oberg (dalam Zapf, 1991:3), seorang antropolog Belanda, menjabarkan tentang gegar budaya (culture shock): "culture shock as a mental illness, an occupational pathology for persons transplanted abroad precipitated by the anxiety that results from losing all our

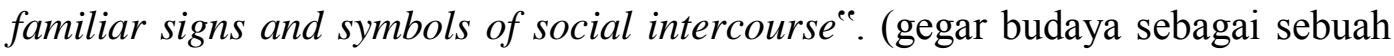
penyakit mental, sebuah patologi kerja bagi orang-orang yang berpindah ke luar negeri yang dipicu oleh kecemasan yang dihasilkan akibat kehilangan semua tanda dan simbol pergaulan yang sebelumnya akrab.

Pada dasarnya, gegar budaya (culture shock) merupakan benturan persepsi yang diakibatkan penggunaan persepsi berdasarkan faktor-faktor internal (nilainilai budaya) dan telah dipelajari orang yang bersangkutan dalam lingkungan baru yang nilai budayanya berbeda dan belum dipahami. Individu biasanya menerima begitu saja nilai-nilai yang dianut dan dibawa sejak lahir, yang dikonfirmasikan oleh orang-orang di sekitarnya. Namun, ketika individu memasuki suatu lingkungan baru, individu tersebut menghadapi situasi yang membuatnya mempertanyakan kembali asumsi-asumsinya, tentang apa yang didsebut kebenaran, moralitas, kebaikan, kewajaran, kesopanan, kebijakan, dan sebagainya. Benturan-benturan persepsi itu kemudian menimbulkan konflik dalam diri individu, dan menyebabkannya merasa tertekan dan menderita stress. Efek stress inilah yang disebut gegar budaya (culture shock) (Mulyana Deddy, 2007: 247249). Ada beberapa faktor yang mempengaruhi gegar budaya yaitu: (1) Faktor Interpersonal, diantaranya keterampilan komunikasi, pengalaman dalam setting lintas budaya, personal (mandiri atau torelansi), dan akses ke sumber daya. Karakteristik fisik seperti penampilan, umur, kesehatan, kemampuan sosialisasi juga mempengaruhi. Individu yang lebih muda cenderung mengalami gegar budaya yang lebih tinggi dari pada individu yang lebih tua dan wanita lebih mengalami gegar budaya dari pada pria (Kazantzis dalam Pederson, 1995). (2) Al-Munzir Vol. 12. No. 1 Mei 2019 
Variasi budaya mempengaruhi transisi dari satu budaya ke budaya lain. Gegar budaya terjadi lebih cepat jika budaya tersebut semakin berbeda, hal ini meliputi sosial, perilaku, adat istiadat, agama, pendidikan, norma dalam masyarakat dan bahasa. (3) Manifestasi sosial politik juga mempengaruhi gegar budaya. Sikap dari masyarakat setempat dapat menimbulkan prasangka, streotype dan intimidasi. Dari pernyataan diatas dapat disimpulkan bahwa gegar budaya dipengaruhi oleh faktor internal dan faktor eksternal yang ada pada diri individu yang bersangkutan. Faktor internalnya adalah adanya pengaruh intrapersonal dalam diri individu sedangkan faktor eksternalnya antara lain adanya variasi antar budaya yang berbeda dan manifestasi sosial politik

\section{C.1 Teori Akomodasi Komunikasi}

Salah satu teori komuikasi yang berubungan dengan pembahasan ini adalahTeori Akomodasi Komunikasi berawal pada tahun 1973. Giles merupakan orang yang pertama kali memperkenalkan pemikiran mengenai model mobilitas aksen, yang didasarkan pada berbagai akses yang dapat didengar dalam situasi wawancara. Akomodasi didefinisikan sebagai kemampuan untuk menyesuaikan, memodifikasi, atau mengatur perilaku seseorang dalam responnya terhadap orang lain (West dan Turner, 2008:217). Communication Accomodation Theory (CAT) memberikan perhatian pada interaksi, memahami antara orang-orang dari kelompok yang berbeda dengan menilai bahasa, perilaku nonverbal dan penggunaan paralinguistik individu (Gudykunst dan Moody, 2002:44). Akomodasi didefinisikan sebagai kemampuan untuk menyesuaikan, memodifikasi, atau mengatur perilaku seseorang dalam memberikan respon kepada orang lain. Hal ini biasanya cenderung dilakukan dalam keadaan tidak sadar. Tujuan inti dari teori akomodasi komunikasi adalah untuk menjelaskan cara-cara dimana orang-orang yang berinteraksi dapat mempengaruhi satu sama lain selama interaksi.

Teori akomodasi komunikasi berfokus pada mekanisme pada dimana proses psikologi sosial mempengaruhi perilaku yang diamati dalam interaksi. Akomodasi merunjuk pada cara-cara dimana individu - individu dalam interaksi, memantau dan mungkin menyesuaikan perilaku mereka selama interaksi (Rohim, 2009:212). Teori akomodasi komunikasi menyatakan bahwa dalam sebuah Al-Munzir Vol. 12. No. 1 Mei 2019 
interaksi, seseorang memiliki pilihan. Mereka mungkin menciptakan komunitas percakapan yang melibatkan penggunaan bahasa atau sistem nonverbal yang sama, mereka mungkin akan membedakan diri mereka dari orang lain, atau mereka akan berusaha keras untuk beradaptasi. Pilihan- pilihan ini diberi label konvergensi, divergensi, dan akomodasi berlebihan.

\section{C.1 Fenomena Gegar Budaya Mahasiswa Universitas Muslim Indonesia}

Objek penelitian dalam penelitian ini berfokus pada fenomena gegar budaya mahasiswa asal luar makassar yang menempuh studi di Kampus Universitas Muslim Indonesia (UMI) Makassar. Mahasiswa asal Bima dan Buton sebelumnya memiliki faktor-faktor tertentu yang mendorong mereka melakukan perantauan, di antaranya adalah untuk melanjutkan studi ke jenjang yang lebih tinggi agar dapat meraih cita-cita juga memiliki masa depan yang lebih cerah.Melakukan perantauan bukanlah suatu hal yang mudah dikarenakan mahasiswa jawa diharuskan hidup mandiri tanpa ada keluarga yang mendampingi, apalagi perantauan dilakukan ke luar pulau yang jaraknya cukup jauh. Ketika datang ke kota perantauan, mahasiswa rantau mengalami kekagetan dengan lingkungan baru yang ditemuinya. Reaksi ini biasanya disebut dengan culture shock atau gegar budaya.

Gegar budaya merupakan salah satu reaksi pada umumnya dimana perantau merasa kaget atas perbedaan yang terjadi mulai dari budaya, bahasa, makanan, kehidupan sosial, cuaca dan sebagainya. Mau tak mau hal ini menyebabkan mahasiswa rantau dituntut untuk melakukan penyesuaian terhadap hal-hal baru yang ada di sekitar. Contohnya ketika mahasiswa asal Bima dan Buton dan Papua harus melakukan komunikasi dengan masyarakat sekitar. Mereka tidak bisa menggunakan bahasa daerah asalnya tetapi mereka harus menyesuaikan diri dengan bahasa di Makassar yang notabene menggunakan bahasa bugis ataupun Makassar. Walaupun tinggal di satu negara yang sama, dialek ataupun makna suatu kata akan memiliki arti yang berbeda di setiap daerahnya. Gaya bicara mahasiswa Bima dan Buton dan Papua pun menjadi kendala dalam berkomunikasi karena dianggap memiliki intonasi yang terlalu rendah bagi masyarakat Makassar.

Ketika seseorang mengalami gegar budaya, hal ini dapat menjadi suatu hal Al-Munzir Vol. 12. No. 1 Mei 2019 
baik ataupun buruk tergantung indiviu memperlakukannya karena reaksi terhadap gegar budaya pada masing-masing individu berbeda. Hal baik akan terjadi jika mahasiswa rantau bisa dengan cepat menyesuaikan diri di lingkungan baru dan berbaur namun jika yang terjadi adalah sebaliknya, maka gegar budaya bisa mempengaruhi keadaan fisik maupun psikis. Maka dari itu mahasiswa Bima dan Buton memilih untuk mengikuti kegiatan di dalam maupun di luar kampus seperti organisasi maupun komunitas untuk mengisi waktu luang serta beradaptasi dengan lingkungan baru.

Fenomena gegar budaya semakin banyak terjadi saat ini karena sudah banyaknya masyarakat yang menempuh studi di luar daerahnya masing-masing, sehingga memacu penulis melakukan penelitian ini yang merupakan bagian dari komunikasi antarbudaya. Selain itu, ilmu komunikasi juga mempunyai peranan penting berkaitan dengan penelitian ini. Objek penelitian berkaitan erat dengan komunikasi antarbudaya. Berdasarkan yang telah dijelaskan sebelumnya, komunikasi antarbudaya terjadi bila pengirim pesan adalah anggota dari suatu budaya dan penerima pesannya adalah anggota dari suatu budaya lain. Komunikasi antarbudaya adalah komunikasi antar orang-orang yang berbeda budaya (baik dalam arti ras, etnik ataupun perbedaan sosioekonomi), hal inilah yang menjadi latar belakang dalam penelitian ini.

\section{C.2 Faktor Pendorong Mahasiswa Buton, Bima dan Papua Melakukan Perantauan}

Tindakan adalah sebuah makna yang rumit atau makna yang kontekstual, oleh karenanya, untuk menggambarkan keseluruhan tindakan seseorang perlu diberi fase. Dua fase yang diusulkan Schutz diberi nama tindakan in-order-to motivate atau "motif untuk" yang merujuk pada masa yang akan datang; dan tindakan because-motive atau "motif sebab" yang Berdasarkan hasil wawancara, key informan 1 yaitu Tami mengungkapkan bahwa ia sangat senang ketika mengetahui dirinya akan melakukan perantauan, karena ia teringat pengalaman masa kecilnya ketika sering berpindah dari satu daerah ke daerah lainnya karena tuntutan pekerjaan orangtuanya. Walaupun waktu pertama kali orangtua Tami tidak mengizinkan dirinya melakukan perantauan mengingat ia merupakan seorang anak perempuan, namun hal tersebut tidak menurunkan tekad Tami untuk Al-Munzir Vol. 12. No. 1 Mei 2019 
merantau karena keinginannya yang besar untuk mengetahui bagaimana situasi dan kondisi di Makassar

Tami menjelaskan rasa senang saat ingin merantau dikarenakan ia akan mendapatkan teman-teman dan lingkungan yang baru, terlebih ia dapat melanjutkan studi dengan jurusan yang diinginkan yaitu Ilmu Komunikasi, sehingga hal inilah yang dapat mendekatkan dan memudahkan Tami dalam mewujudkan cita-citanya menjadi seorang jurnalis. Dipilihnya kampus UMI oleh Tami dikarenakan UMI memiliki passing grade yang Baik yang sekiranya dapat dijangkau ketika ia melakukan test SNMPTN. Sebelumnya Tami sama sekali tidak mempunyai gambaran tentang situasi dan kondisi Kampus UMI maupun Makassar, tetapi karena faktor cita-citanya menjadi jurnalis itu yang membuatnya menjadi nekat melakukan perantauan. Hal ini menjelaskan jika Tami mempunyai tujuan ataupun "motif untuk" dalam melakukan perantauan karena Tami melihat dirinya di masa depan.Keinginan Tami menjadi jurnalis ini dilatarbelakangi atau "motif sebab" dari masa kecilnya yang sempat menonton berita tentang wartawan yang sedang meliput perang lalu dijadikan tawanan karena dikira penyusup. Hal ini membuat Tami tertarik menjadi jurnalis.

Sama seperti Tami, key informan kedua, Rudi . Anak dari seorang guru ini merasa senang ketika mengetahui akan merantau jauh dari kampung halaman, terutama ke pulau sulawesi yang dianggapnya memiliki pendidikan yang lebih baik dari pada pula papua . Hal inilah yang menjadi "motif sebab" yang mendorong Rudi melakukan perantauan.

Merantaunya Rudi ke Makassar didukung oleh sang ibu dimana ibunya yang merupakan seorang guru merasa pendidikan di Pulau Makassar jauh lebih memadai dan bergengsi dari pada Pulau Papua, oleh karena itu ibunya meminta Rudi untuk mengikuti test SNMPTN. Dipilihnya UMI sebagai kampus tujuan juga dikarenakan saran dari ibu Rudi yang sebelumnya mengetahui tentang Kampus UMI dari mantan muridnya yang berkuliah di UMI. Dalam hal ini, Rudi memiliki "motif untuk" melanjutkan pendidikan ke jenjang yang lebih tinggi.

Sedangkan key informan ketiga yang bernama Rienny mengaku sempat merasa sedih sebelumnya ketika mengetahui akan berkuliah di UMI karena ia tidak diterima di Universitas pilihan pertamanya, namun kesedihan tersebut Al-Munzir Vol. 12. No. 1 Mei 2019 
dialihkan oleh Rienny dimana ia percaya akan mendapat seseuatu hal yang berarti di UMI seperi teman, pengalaman dan suasana baru. Selain itu Rienny juga ingin sekali merasakan hal yang sebelumnya dirasakan oleh kakak laki-lakinya yang sudah merantau terlebih dahulu ke Makassar, hal inilah yang menjadi faktor penyebab Rienny melakukan perantauan.

Individu melakukan suatu tindakan disebabkan oleh motif-motif tertentu yang dimana memiliki tujuan dan sebabnya tersendiri. Sama halnya dengan Informan 3 yaitu Rienny yang melakukan perantauan dikarenakan memiliki tujuan untuk berkuliah. Hal tersebut didasari oleh pandangan Rienny yang melihat peluang dalam mencari kerja di masa depan karena pendidikan tinggi merupakan suatu modal untuk mendapatkan pekerjaan yang lebih baik, selain itu dipilihnya jurusan Teknik Industri juga karena menurut Rienny, jurusan inilah yang lebih banyak memiliki peluang pekerjaan dari pada jurusan lainnya. Sayangnya, di kampung halaman Rienny yaitu Bima tidak memiliki fasilitas pendidikan yang diinginkan oleh Rienny sehingga ia memilih Kampus UMI sebagai tempat untuk menempuh pendidikan karena didasari oleh beberapa hal yaitu, UMI merupakan Universitas Swasta, memiliki jurusan Teknik Industri yang berkareditasi B dan memiliki passing grade yang lebih rendah sehingga dapat dijangkau oleh Rienny ketika mengikuti test SNMPTN.

\section{C.3 Proses Interaksi Mahasiswa Perantauan di UMI}

Konsep intersubjektifitas dalam fenomenologi Schutz merupakan konsep yang memungkinkan kita melakukan interaksi dalam komunikasi. Dengan bekal karakteristik persediaan pengetahuan yang dimiliki, maka dapat saling berbagi perspektif dengan orang lain, dapat melakukan berbagai macam hubungan dengan orang lain. Pandangan Schutz, kategori pengetahuan, derajat pertama bersifat pribadi dan unik bagi setiap individu dalam interaksi tatap muka dengan orang lain. Kemudian berbagai pengkhasan yang telah terbentuk dan dianut semua anggota suatu budaya, terdiri dari mitos, pengetahuan, budaya dan akal sehat. Maka tujuan utama analisis fenomenologis adalah mengkonstruksi dunia kehidupan manusia "sebenarnya" dalam bentuk yang mereka alami sendiri. Realitas dunia tersebut bersifat intersubjektif, dalam arti bahwa anggota masyarakat berbagai persepsi dasar mengenai dunia yang mereka internalisasikan Al-Munzir Vol. 12. No. 1 Mei 2019 
melalui sosialisasi dan memungkinkan melakukan interaksi.

Dalam penelitian ini, pemahaman baru yang tercipta ketika seseorang sedang melakukan perantauan terbentuk dari interaksi atau hubungan yang dilakukan dengan orang lain. Ketika seseorang berusaha melakukan penyesuaian dikarekana adanya perbedaan-perbedaan antara kampung halaman dan kota perantauan.

Key informan 1 yaitu Tami mengungkapkan ada beberapa hal yang berbeda antara Bima dimana terdapat perbedaan bahasa, adat, kebiasaan, dan juga makanan. Pada awal datang ia belum terbiasa dengan makanan-makanan di Makassar. Dalam hal bahasa pun ia harus menghilangkan logat khas daerahnya dari yang campuran mesti dilakukan. Tami sempat mengalami miskomunikasi atau kesalah pahaman ketika berbicara dengan mahasiswa non Bima, oleh karena itu Tami tidak malu untuk bertanya ke teman-temannya jika ada kata ataupun kalimat yang tidak ia mengerti.

\section{D.Penutup}

Faktor yang mendorong mahasiswa untuk merantau adalah faktor pendidikan, faktor ekonomi, dan faktor budaya. Kelima key informan memiliki harapan atau ekspektasi ketika akan melakukan perantauan serta motif untuk berkuliah dan menggapai cita-cita, hal ini juga termasuk ke dalam fase kegembiraan.

Proses interaksi yang dialami oleh mahasiswa Buton, Bima dan Papua di perantauan diakibatkan adanya fase kekecewaan yang dimana terlihat banyaknya perbedaan antara kampung halaman dan kota perantauan sehingga memicu terjadinya penyesuaian terhadap hal-hal yang baru di perantauan, sehingga adanya pertukaran makna, persepsi dan perspektif, sehingga hal ini termasuk ke dalam fase awal resolusi.

Untuk mengatasi gegar budaya, ketiga key informan mengisi kegiatan sehari-hari dengan mengikuti organisasi maupun komunitas di dalam dan luar kampus. Sehingga hal ini membuat key informan lebih banyak berinteraksi dengan mahasiswa lokal juga lebih mengenal situasi dan kondisi di lingkungan sekitar, selain itu masalah-masalah yang menjadi kendala sebelumnya dapat Al-Munzir Vol. 12. No. 1 Mei 2019 
teratasi karena adanya keterbiasaan dan hal ini termasuk ke dalam fase berfungsi dengan efektif.

\section{Daftar Pustaka}

Bungin, Burhan. 2009. Metodologi Penelitian Kualitatif. Jakarta: Kencana Predana Grup.

Effendy, Onong Uchjana. 2004. Dinamika Komunikasi. Bandung: PT Remaja Rosdakarya.

Elvinaro, Ardianto dan Bambang Q. 2007. Filsafat Ilmu Komunikasi. Bandung: simbiosa rekatama Media.

Goodman, Douglas J dan George Ritzer. 2007. Teori Sosiologi Modern. Jakarta: Kencana.

Hafied. 2008. Pengantar Ilmu Komunikasi. Jakarta: PT. Raja Grafindo Persada. Hidayat, Dedy N. 2003. Paradigma dan Metodologi Penelitian Sosial Empirik

Klasik. Jakarta: Departemen Ilmu Komunikasi FISIP Universitas Indonesia.

Kevinzky, Muhammad Haiqal. 2011. Proses dan Dinamika Komunikasi Dalam Menghadapi Culture Shock Pada Adaptasi Mahasiswa Perantauan (Kasus Adaptasi Mahasiswa Perantau di UNPAD Bandung). Depok: FISIP UI.

Kriyantono, Rachmat. 2012. Teknik Praktis Riset Komunikasi. Jakarta: Kencana. Kuswarno, Engkus. 2009. Metode Penelitian Komunikasi Fenomenologi:

Liliweri, Alo. 2011. Dasar-Dasar Komunikasi Antarbudaya. Yogyakarta: Pustaka Pelajar.

Littlejohn, Stephen W. \& Karen A.Foss. 2005. Theories Of Human Communication. 8 ed. Canada: Wadsworth.

Lubis, Lusiana Andriana. 2002. Penerapan Komunikasi Lintas Budaya di Antara Perbedaan Budaya. Medan: Digitalized by USU digital library.

MAO, Yingjuan. "Living in the bubble" The Role of communication for Swedish adjustment in China. 2014. Gothenburg: University of Gothenburg Department of Applied Information Technology. 
Moleong, Lexy J. 2006. Metodologi Penelitian Kualitatif. Bandung: Remaja Rosdakarya.

Al-Munzir Vol. 12. No. 1 Mei 2019 